\title{
Overweight and associated factors in young adult student girls
}

\author{
Excesso Ponderal e fatores associados em mulheres adultas jovens escolares \\ Exceso Ponderal y factores asociados en mujeres adultas jóvenes escolares
}

\begin{abstract}
Raquel Rodrigues da Costa', Thereza Maria Magalhães Moreira', Raquel Sampaio Florêncio', Vera Lúcia Mendes de Paula Pessoa', Virna Ribeiro Feitosa Cestari', Francisca Gomes Montesuma'

'Universidade Estadual do Ceará. Fortaleza, Ceará, Brazil.
\end{abstract}

How to cite this article:

Costa RR, Moreira TMM, Florêncio RS, Pessoa VLMP, Cestari VRF, Montesuma FG. Overweight and associated factors in young adult student girls. Rev Bras Enferm [Internet]. 2018;71(6):2990-7. DOI: http://dx.doi.org/10.1590/0034-7167-2017-0838

\author{
Submission: 02-15-2018 Approval: 03-01-2018
}

\begin{abstract}
Objective: To analyze overweight and associated factors in young adult student girls children in a capital city of Northeast Brazil. Method: An analytical, quantitative study was conducted with 546 young adults from 26 schools in a capital city of the Brazilian Northeast. After obtaining the data by the application of a specific questionnaire, the hierarchical logistic regression was used to identify the confounding variables and predictors of overweight. Results: The frequency of cases of overweight in this group was $36.6 \%$. In the bivariate analysis, Overweight presented a statistically significant association with ethnicity, marital status, weight in childhood and overweight in adolescence, overweight in the family and exposure to alcohol, number of children, and age of menarche. In the final regression model, overweight remained associated with weight in childhood and age of menarche. Conclusion: Characteristics related to nutritional status in earlier life stages and gynecological issues were associated with Overweight during the young adult stage of the woman.
\end{abstract}

Descriptors: Overweight; Obesity; Women's Health; Young Adult; Nursing.

\section{RESUMO}

Objetivo: Analisar o Excesso Ponderal (EP) e os fatores associados em mulheres adultas jovens escolares de uma capital do Nordeste brasileiro. Método: Estudo analítico, quantitativo, realizado com 546 adultas jovens de 26 escolas de uma capital do Nordeste brasileiro. Após obtenção dos dados pela aplicação de questionário específico, utilizou-se a regressão logística hierarquizada para identificação das variáveis confundidoras e preditoras do EP. Resultados: A frequência de casos de EP nesse grupo foi de 36,6\%. Na análise bivariada, o EP apresentou associação estatisticamente significativa com raça, situação conjugal, peso na infância e peso elevado na adolescência, EP na família e exposição ao álcool, número de filhos, e idade da menarca. No modelo final da regressão, o EP permaneceu associado com peso na infância e idade da menarca. Conclusão: Características relacionadas ao estado nutricional em fases anteriores da vida e questões ginecológicas estiveram associadas ao EP durante a fase adulta jovem da mulher.

Descritores: Sobrepeso; Obesidade; Saúde da Mulher; Adulto Jovem; Enfermagem.

\section{RESUMEN}

Objetivo: Analizar el Exceso Ponderal (EP) y los factores asociados en mujeres adultas jóvenes escolares de una capital del Nordeste brasileño. Método: Estudio analítico, cuantitativo, realizado con 546 adultos jóvenes de 26 escuelas de una capital del Nordeste brasileño. Después de obtener los datos por la aplicación de cuestionario específico, se utilizó la regresión logística jerarquizada para identificación de las variables confundidoras y predictoras del EP. Resultados: La frecuencia de casos de EP en ese grupo fue del 36,6\%. En el análisis bivariado, el EP presentó asociación estadísticamente significativa con raza, situación conyugal, peso en la infancia y peso elevado en la adolescencia, EP en la familia y exposición al alcohol, número de hijos, y edad de la menarca. En el modelo final de la regresión, el EP permaneció asociado con peso en la infancia y edad de la menarca. Conclusión: Las características relacionadas con el estado nutricional en fases anteriores de la vida y las cuestiones ginecológicas estuvieron asociadas al EP durante la fase adulta joven de la mujer.

Descriptores: Sobrepeso; Obesidad; Salud de la Mujer; Adulto Joven; Enfermería. 


\section{INTRODUCTION}

Overweight has been associated with adverse health effects in women in the short and long term. Women with this nutritional situation present reduced reproductive capacity and increase the risk of adverse outcomes during pregnancy. However, several reproductive cycle factors can be considered as risk factors for overweight, a condition that leads to the development of diabetes and cardiovascular disease ${ }^{(1)}$.

At the same time, overweight has also intensified among young people of different ages throughout the industrialized world ${ }^{(2)}$. There is already evidence of an increased prevalence of overweight in children and adolescents ${ }^{(3-7)}$. However, the population of young adult women has not been considered in the surveys with the same intensity. In the few studies that have addressed this population in the age group advocated by the Brazilian Ministry of Health and the World Health Organization (20 to 24 years) $)^{(1,4,7)}$, the frequency of overweight cases already reaches one third ${ }^{(2,8-9)}$. Although in some studies this prevalence is presented, the question of risk factors or protection is not considered.

Thus, there is a lack of research that addresses the issue of overweight in young adult women, requiring greater attention to these young women, who present peculiar characteristics in this phase of life. Women present additional characteristics that increase their chances of overweight when compared to men, such as: gestation and increase of the first gestation age, hormonal influence, income, among others ${ }^{(10)}$. In addition, since most studies on overweight are focused on children and adolescents, it is necessary that other groups are also studied in other phases of life, especially young adulthood, since the majority studies and does not yet have a routine characteristic of the mature adult, being possible to acquire new behaviors with greater ease, mainly in the spaces of learning ${ }^{(11)}$.

It is in the younger strata of the population that the measures directed to the changes of behavior can provide greater effect, being, thus, the age group focused in this effective study to the concentration of efforts directed to the fight against overweight.

Among the many spaces in which health education practices are developed to inform people about the risk situations they are exposed to, school is considered a crucial space. The nurse assumes a fundamental role in this area, promoting health education in order to raise the awareness of the young population that their health is intertwined with lifestyle, and to make young people aware of the abandonment of risk behaviors to ensure a healthier life ${ }^{(12)}$. In this sense, due to the growth of overweight and obesity in the young adult population, it is noticed the need of nurses acting in their prevention, aiming to improve the health of the group in question ${ }^{(8-9)}$.

In this context, we ask: What are the factors associated with overweight in young adult student children? Responding to this questioning becomes relevant for the planning of specific education and health promotion actions for the study population in the school context.

\section{OBJECTIVE}

To analyze overweight and associated factors in young adult student girls from a Brazilian Northeast capital.

\section{METHOD}

\section{Ethical aspects}

The development of this research complied with ethical and legal precepts in all phases, according to what was recommended by Resolution 466/2012 of the National Health Council (Conselho Nacional de Saúde) ${ }^{(13)}$. The present study was approved by the Research Ethics Committee of the Universidade Estadual do Ceará. The participants were clarified about the purpose of the study and signed the Free and Informed Consent Term and are integrated into a funded "umbrella" project.

\section{Design, place of study and period}

This is an analytical study, with a quantitative approach, carried out from October 2013 to October 2016 in 26 state schools in a capital city of Brazilian Northeast.

\section{Population or sample; criteria of inclusion and exclusion}

This research integrates a funded project, whose universe of study was composed of young adults of the municipality with or without overweight. The calculation of the "umbrella" project sample was as follows: $n=t^{2} 5 \% \times P \times Q / e^{2}$, where: " $n$ " is the sample; " $\mathrm{t}$ " is the student $\mathrm{t}$ distribution value or significance level $(t=1.96)$; " $P$ " is the prevalence of the phenomenon (considered here in $50 \%$, as it is unknown in the age group under study); " $\mathrm{Q}$ " is the complementary percentage of $\mathrm{P}(\mathrm{Q}=100-\mathrm{P})$; " $\mathrm{e}$ " is the sample error (here considered at $3 \%$ ). Based on the result of the calculation, a sample of 1067 young adult student girls and boys, chosen for convenience in 51 schools, was obtained. For this study, the sample was represented by all the women included in the larger research database, totaling 546 young adult student girls and boys from 26 schools.

As an exclusion criterion in the sample of the "umbrella" project and the present project, it was established: Being pregnant (considering other parameters for overweight identification) and moving in wheelchairs, since there were no means available to perform anthropometric measurements in this group. When such cases occurred, other young women were included.

\section{Study protocol}

The management and/or school coordination was contacted and the days of collection were marked, according to availability of the institution. Visits were then carried out in all classrooms, explained the research and invited young people in the age group pre-established to participate in the study. When the invitation was accepted, the girls were referred to a specific room, where the research questionnaires were applied and the anthropometric parameters were measured. Data collection was carried out in three phases: 1 ) selection and sensitization of schools; 2) application of a questionnaire to collect data regarding sociodemographic characteristics, behavioral situation and birth and gynecological status; and 3) verification of anthropometric measures (weight and height).

Anthropometric measures were measured in a standardized way and recorded in the questionnaire. The weight was determined by the G-TECH ${ }^{\circledR}$ brand balance, duly calibrated for adults, with the participant standing and arms with the least 
weight of clothing possible and without shoes. For height, the subjects remained standing, feet together and arms extended along the body and without shoes, using inextensible tape measure adhered to a wall without skirting.

Overweight (BMI> $25 \mathrm{~kg} / \mathrm{m} 2$ ) was verified by the BMI in $\mathrm{kg} / \mathrm{m}^{2}$, calculated using the Quetelet index; the result was then classified into low weight, normal weight, overweight or obesity I, II and III, the last four classes being grouped, characterizing the dependent variable ${ }^{(10)}$. The independent variables (all categorical) were investigated according to three chuncks: 1) Sociodemographic characteristics; 2) Behavioral situation and; 3) Birth and gynecological status. The data, as soon as collected, followed for construction of the database in a software.

\section{Analysis of results and statistics}

The simple and percentage frequencies of the variables were initially calculated and, subsequently, the bivariate and multivariate statistics were used.

In the bivariate analysis, the Pearson Chi-square test was performed, considering in all the tests the level of statistical significance of $5 \%$. To estimate the association strength of the independent variables in relation to the dependent variable, the Odds Ratio (OR) was calculated, with a confidence interval of $95 \%$.

In the multivariate analysis, the statistical procedure for adjusting the potential confounding effects was the hierarchical multiple logistic regression. For the ordering of the introduction of the variables in the model, the hierarchical level of each exposure variable in the overweight determination chain was considered. The hierarchy of the variables followed the sequence: 1) variables located in the hierarchical level of lower power of determination of overweight (sociodemographic); 2) variables located at the intermediate hierarchical level (behavioral situation); 3) variables located at the hierarchical level closest to the effect (birth and gynecological situation).

For inclusion in the initial regression model, as a way to verify the confounding variables, we adopted the $P$ value $<0.20$ obtained in the bivariate analysis. The criterion established in this stage of analysis for the variables remained in the model was the Wald test presented at least one category with a statistical significance of $P$ value $<0.05$. The method of data entry in all phases of the regression was forced enter.

The data were processed, analyzed and presented through tables in order to clarify the disclosure and organization of the information regarding the proposed by the objective. Next, the results were reviewed according to the literature reviewed and pertinent to the subject under study, in order to produce evidence.

\section{RESULTS}

Of the total women in the age group of 20 to 24 years, the prevalence of overweight was 39.6\% (BMI> $\left.25 \mathrm{~kg} / \mathrm{m}^{2}\right)$. As far as sociodemographic characteristics were concerned, it was observed that the young adults presented in the majority age group of 20 to 22 years $(75.6 \%)$, most of them self-reported ethnicity/color distinct from white $(87.7 \%)$ and $73.8 \%$ of the women had no partner. Concerning occupation and income, a little more than half reported studying and working/interning (54\%), the vast majority (93\%) had individual income of up to two minimum wages and half (50\%) had family income of up to two minimum wages (Table 1).

Behavioral data were also identified in this study, such as: Weight in childhood $(8.4 \%)$, weight in adolescence $(14.7 \%)$ and presence of overweight in the family (46.2\%), exposure to alcohol (31.1\%), unbalanced diet (79.9\%) and level of physical activity, where $72.2 \%$ of the women were vigorously inactive, and $47.1 \%$ were moderately inactive (Table 1 ).

In Table 1, more than half of the young adult women were born in a normal birth (68.7\%), 20.3\% increased more than 16 kilos during pregnancy, and the majority (70.0\%) had no children. Of the total number of young adult women, $16.3 \%$ had the first child younger than 16 years of age, $50.5 \%$ of the women had menarche under the age of 12 years and $11 \%$ had self-reported micropolycystic ovary.

Table 1 - Univariate and bivariate analysis of socio-demographic, behavioral/family and birth/gynecological characteristics associated with overweight in young adult student girls and boys, Fortaleza, Ceará State, Brazil, 2016

\begin{tabular}{|c|c|c|c|c|c|}
\hline \multirow{2}{*}{ Variables } & \multirow{2}{*}{$\begin{array}{l}\text { Total } \\
f(\%)\end{array}$} & \multicolumn{2}{|c|}{ Overweight } & \multirow{2}{*}{$p$ value } & \multirow{2}{*}{ OR (Cl 95\%) } \\
\hline & & Yes $f(\%)$ & No $f(\%)$ & & \\
\hline \multicolumn{6}{|l|}{ Chunck 1} \\
\hline \multicolumn{6}{|l|}{ Age group } \\
\hline 20 to 22 years & $413(75.6)$ & $155(37.5)$ & $258(62.5)$ & 0.062 & $0.682(0.456-1.020)$ \\
\hline 23 to 24 years & $127(23.3)$ & $59(46.8)$ & $67(53.2)$ & & 1 \\
\hline \multicolumn{6}{|l|}{ Self-reported ethnicity/color } \\
\hline White & $60(11.0)$ & $34(56.7)$ & $26(43.3)$ & 0.005 & $2.146(1.247-3.693)$ \\
\hline Others & $479(87.7)$ & $181(37.9)$ & $297(62.1)$ & & 1 \\
\hline \multicolumn{6}{|l|}{ Marital status } \\
\hline With companion & $140(25.6)$ & $68(48.6)$ & $72(51.4)$ & 0.011 & $1.656(1.123-2.443)$ \\
\hline Without companion(a) & $403(73.8)$ & $146(36.3)$ & $256(63.7)$ & & 1 \\
\hline \multicolumn{6}{|l|}{ Individual income } \\
\hline Up to 2 minimum wages & $508(93.0)$ & $202(39.8)$ & $305(60.2)$ & 0.871 & $0.883(0.196-3.987)$ \\
\hline More than 2 minimum wages & $7(1.3)$ & $3(42.9)$ & $4(57.1)$ & & 1 \\
\hline
\end{tabular}




\begin{tabular}{|c|c|c|c|c|c|}
\hline \multirow{2}{*}{ Variables } & \multirow{2}{*}{$\begin{array}{l}\text { Total } \\
f(\%)\end{array}$} & \multicolumn{2}{|c|}{ Overweight } & \multirow{2}{*}{$p$ value } & \multirow{2}{*}{ OR (Cl 95\%) } \\
\hline & & Yes $f(\%)$ & No $f(\%)$ & & \\
\hline \multicolumn{6}{|l|}{ Family income } \\
\hline Up to 2 minimum wages & $273(50.0)$ & $112(41.0)$ & $161(59.0)$ & 0.978 & $0.994(0.642-1.539)$ \\
\hline More than 2 minimum wages & $119(21.8)$ & $49(41.2)$ & $70(58.8)$ & & 1 \\
\hline \multicolumn{6}{|l|}{ Occupation } \\
\hline Yes & $295(54.0)$ & $113(38.4)$ & $181(61.6)$ & 0.627 & $0.917(0.648-1.299)$ \\
\hline No & $242(44.3)$ & $98(40.5)$ & $144(59.5)$ & & 1 \\
\hline \multicolumn{6}{|l|}{ Chunck 2} \\
\hline \multicolumn{6}{|l|}{ Weight in childhood } \\
\hline Overweight & $46(8.4)$ & $32(69.6)$ & $14(30.4)$ & 0.000 & $3.84(1.993-7.399)$ \\
\hline Normal weight & $462(84.6)$ & $172(37.3)$ & $289(62.7)$ & & 1 \\
\hline \multicolumn{6}{|l|}{ Weight in adolescence } \\
\hline Overweight & $80(14.7)$ & $55(69.6)$ & $24(30.4)$ & 0.000 & $4.492(2.675-7.542)$ \\
\hline Normal weight & $444(81.3)$ & $150(33.8)$ & $294(66.2)$ & & 1 \\
\hline \multicolumn{6}{|c|}{ Presence of overweight in the family } \\
\hline Yes & $252(46.2)$ & $117(46.6)$ & $134(53.4)$ & 0.010 & $1.623(1.121-2.351)$ \\
\hline No & $223(40.8)$ & $78(35.0)$ & $145(65.0)$ & & 1 \\
\hline \multicolumn{6}{|l|}{ Exposure to alcohol } \\
\hline Yes & $170(31.1)$ & $78(45.9)$ & $92(54.1)$ & 0.046 & $1.459(1.006-2.116)$ \\
\hline No & $352(64.5)$ & $129(36.8)$ & $222(63.2)$ & & 1 \\
\hline \multicolumn{6}{|l|}{ Vigorously active } \\
\hline Yes & $145(26.6)$ & $55(37.9)$ & $90(62.1)$ & 0.632 & $1.100(0.744-1.627)$ \\
\hline No & $394(72.2)$ & $158(40.2)$ & $235(59.8)$ & & 1 \\
\hline \multicolumn{6}{|l|}{ Moderately active } \\
\hline Yes & $274(50.2)$ & $107(39.2)$ & $166(60.8)$ & 0.835 & $1.038(0.732-1.470)$ \\
\hline No & $257(47.1)$ & $103(40.1)$ & $154(59.9)$ & & 1 \\
\hline \multicolumn{6}{|l|}{ Balanced diet } \\
\hline Yes & $98(17.9)$ & $31(31.6)$ & $67(68.4)$ & 0.062 & $1.555(0.975-2.479)$ \\
\hline No & $436(79.9)$ & $182(41.8)$ & $253(58.2)$ & & 1 \\
\hline \multicolumn{6}{|l|}{ Chunck 3} \\
\hline \multicolumn{6}{|l|}{ Type of birth } \\
\hline C-section & $123(22.5)$ & $43(35.0)$ & $80(65.0)$ & 0.310 & $0.803(0.525-1.227)$ \\
\hline Normal & $375(68.7)$ & $150(40.1)$ & $224(59.9)$ & & 1 \\
\hline \multicolumn{6}{|l|}{ Children } \\
\hline Yes & $142(26.0)$ & $73(51.4)$ & 69 (48.6) & 0.000 & $2.067(1.397-3.057)$ \\
\hline No & $382(70.0)$ & $129(33.9)$ & $252(66.1)$ & & 1 \\
\hline \multicolumn{6}{|c|}{ How much weight gained in pregnancy } \\
\hline$\geq 16 \mathrm{Kg}$ & $48(8.8)$ & $30(62.5)$ & $18(37.5)$ & 0.055 & $1.961(0.980-3.923)$ \\
\hline$<16 \mathrm{~kg}$ & $111(20.3)$ & $51(45.9)$ & $60(54.1)$ & & 1 \\
\hline \multicolumn{6}{|l|}{ Age that had the first child } \\
\hline$<18$ years & $89(16.3)$ & $50(56.2)$ & $39(43.8)$ & 0.111 & $1.629(0.893-2.970)$ \\
\hline$\geq 18$ years & $84(15.4)$ & $37(44.0)$ & $47(56.0)$ & & 1 \\
\hline \multicolumn{6}{|l|}{ Age of menarche } \\
\hline$<12$ years & $90(16.5)$ & $52(57.8)$ & $38(42.2)$ & 0.000 & $2.395(1.474-3.890)$ \\
\hline$\geq 12$ years & $276(50.5)$ & $100(36.4)$ & $175(63.6)$ & & 1 \\
\hline \multicolumn{6}{|c|}{ Self-reported presence of micropolycystic ovary } \\
\hline Yes & $60(11.0)$ & $29(48.3)$ & $31(51.7)$ & 0.176 & $1.457(0.843-2.519)$ \\
\hline No & $377(69.0)$ & $147(39.1)$ & $229(60.9)$ & & 1 \\
\hline
\end{tabular}

Note: f: Absolute frequency; p-value: significance level of Pearson's Chi-Square Test. OR: Odds Ratio; Cl: Confidence Interval

On the bivariate analysis, they presented a statistically significant association with overweight $(p<0.05)$ : 1$)$ selfreported ethnicity/color and marital status; 2 ) weight in childhood, weight in adolescence, overweight in the family and exposure to alcohol; and 3) children and age of menarche (Table 1).

For the entry into the initial regression model, we selected the variables that obtained $p<0.20$ in the bivariate analysis 
in each of the chuncks: 1) age group, ethnicity/marital status; 2) weight in childhood and adolescence, overweight in the family, exposure to alcohol, and balanced diet; e 3) variables children, how much weight gained in pregnancy, age that had the first child, age of menarche, self-reported presence of micropolycystic ovary.

When the variables with $p<0.20$ were identified, the multivariate analysis was performed, with the initial adjustment stage (Table
Table 2 - Multivariate analysis of socio-demographic, behavioral/family history and birth/ gynecological characteristics by chuncks associated with Overweight in schoolaged adults, Fortaleza, Ceará State, Brazil, 2016

\begin{tabular}{|c|c|c|}
\hline Variables & $\mathrm{OR}^{\mathrm{a}}(\mathrm{Cl}$ 95\%) & $p$ value \\
\hline Chunck 1 & & \\
\hline $\begin{array}{l}\text { Age group } \\
20 \text { to } 22 \text { years } \\
23 \text { to } 24 \text { years }\end{array}$ & $\begin{array}{c}0.724(0.478-1.097) \\
1\end{array}$ & 0.127 \\
\hline $\begin{array}{l}\text { Self-reported ethnicity/color } \\
\text { White } \\
\text { Brown/Black/Other }\end{array}$ & $\begin{array}{c}2.039(1.178-3.528) \\
1\end{array}$ & 0.011 \\
\hline $\begin{array}{l}\text { Marital status } \\
\text { With companion } \\
\text { Without companion }\end{array}$ & $\begin{array}{c}1.523(1.023-2.269) \\
1\end{array}$ & 0.038 \\
\hline Chunck 2 & & \\
\hline $\begin{array}{l}\text { Self-reported weight in childh } \\
\text { Overweight } \\
\text { Normal weight }\end{array}$ & $\begin{array}{c}2.922(1.292-6.610) \\
1\end{array}$ & 0.010 \\
\hline $\begin{array}{l}\text { Self-reported weight in adoles } \\
\text { Overweight } \\
\text { Normal weight }\end{array}$ & $\begin{array}{c}4.807(2.474-9.341) \\
1\end{array}$ & 0.000 \\
\hline $\begin{array}{l}\text { Presence of overweight in the } \\
\text { Yes } \\
\text { No }\end{array}$ & $\begin{array}{c}1.308(0.855-2.001) \\
1\end{array}$ & 0.215 \\
\hline $\begin{array}{l}\text { Exposure to alcohol } \\
\text { Yes } \\
\text { No }\end{array}$ & $\begin{array}{c}1.453(0.927-2.277) \\
1\end{array}$ & 0.103 \\
\hline $\begin{array}{l}\text { Balanced diet } \\
\text { Yes } \\
\text { No }\end{array}$ & $\begin{array}{c}1.375(0.795-2.378) \\
1\end{array}$ & 0.254 \\
\hline Chunck 3 & & \\
\hline $\begin{array}{l}\text { Children } \\
\text { Yes } \\
\text { No }\end{array}$ & $\begin{array}{c}0.399(0.033-4.894) \\
1\end{array}$ & 0.473 \\
\hline $\begin{array}{l}\text { How much weight gained in } p \\
\quad \geq 16 \mathrm{Kg} \\
<16 \mathrm{~kg}\end{array}$ & $\begin{array}{c}2.615(1.043-6.553) \\
1\end{array}$ & 0.040 \\
\hline $\begin{array}{l}\text { Age that had the first child } \\
\quad<18 \text { years } \\
\geq 18 \text { years }\end{array}$ & $\begin{array}{c}1.211(0.529-2.770) \\
1\end{array}$ & 0.651 \\
\hline $\begin{array}{l}\text { Age of menarche } \\
\quad<12 \text { years } \\
\geq 12 \text { years }\end{array}$ & $\begin{array}{c}3.050(1.156-8.045) \\
1\end{array}$ & 0.024 \\
\hline $\begin{array}{l}\text { Self-reported presence of microp } \\
\text { Yes } \\
\text { No }\end{array}$ & $\begin{array}{c}1.811(0.459-7.150) \\
1\end{array}$ & 0.397 \\
\hline
\end{tabular}

Note: $P$ value-: Significance level of the Pearson Chi-Square Test. ORa: Odds Ratio adjusted; Cl: Confidence Interval.
2). When analyzing the effect of the variables in chuncks on Overweight by the sociodemographic characteristics (chunck 1), they remained significant: self-reported ethnicity/color and marital status ( $p<0.05$ ), according to what is presented in table 2. At chunck 2 we analyzed the effect of chunck variables on overweight by behavioral characteristics, remaining significant ( $p<0.05)$ : weight in childhood and adolescence.

Afterwards, the effect of the chunck variables on Overweight was analyzed by chunck 3 and gestational characteristics, and the variables: how much weight gained in pregnancy and age of menarche ( $p<0.05)$ (Table 2).

Table 3 shows the variables that remained in the final analysis model. Multiple logistic regression was performed with chuncks 1, 2 and 3, which presented $p<0.05$ in the fit between the chuncks. In this final stage, it was detected that self-reported ethnicity/ color and marital status did not maintain a statistically significant association $(p=0.924$; $p=0.858$ ) and therefore were withdrawn from the model, as well as weight in adolescence and how much weight gained in pregnancy $(p=0.554$, $\mathrm{p}=0.069$ ).

After removing the variables ethnicity, marital status, weight in adolescence and how much weight gained in pregnancy, which did not maintain statistical significance in the last stage of multiple logistic regression, the final model presented as predictors of overweight the weight in childhood and age of menarche (Table 4). 
Table 3 - Hierarchical models of overweight predictors in adult student girls and boys, Fortaleza, Ceará, Brazil, 2016

\begin{tabular}{|c|c|c|c|c|}
\hline Variables & $\begin{array}{c}\text { OR }^{\mathrm{a}}(\mathrm{Cl} \text { 95\%) } \\
\text { Model } 1\end{array}$ & $p$ value & $\begin{array}{c}\text { OR }^{\mathrm{a}}(\mathrm{Cl} 95 \%) \\
\text { Model } 2\end{array}$ & $p$ value \\
\hline \multicolumn{5}{|c|}{ Self-reported ethnicity/color } \\
\hline White & $1.062(0.305-3.696)$ & 0.924 & - & - \\
\hline Brown/Black/Other & 1 & & - & \\
\hline \multicolumn{5}{|l|}{ Marital status } \\
\hline With companion & $1.074(0.492-2.346)$ & 0.858 & - & - \\
\hline Without companion & 1 & & - & \\
\hline \multicolumn{5}{|l|}{ Weight in childhood } \\
\hline Overweight & $12.866(1.429-115-828)$ & 0.023 & $4.893(2.271-10.544)$ & 0.000 \\
\hline Normal weight & 1 & & 1 & \\
\hline \multicolumn{5}{|l|}{ Weight in adolescence } \\
\hline Overweight & $1.470(0.410-5.265)$ & 0.554 & - & - \\
\hline Normal weight & 1 & & - & - \\
\hline \multicolumn{5}{|c|}{ How much weight gained in pregnancy } \\
\hline$\geq 16 \mathrm{Kg}$ & $2.245(0.939-5.366)$ & 0.069 & - & - \\
\hline$<16 \mathrm{~kg}$ & 1 & & - & \\
\hline \multicolumn{5}{|l|}{ Age of menarche } \\
\hline$<12$ years & $3.504(1.451-8.462)$ & 0.005 & $2.403(1.454-3.972)$ & 0.001 \\
\hline$\geq 12$ years & 1 & & 1 & \\
\hline
\end{tabular}

Note: $P$ value: Significance level of the Pearson Chi-Square Test. ORa: Odds Ratio adjusted; CI: Confidence Interval.

Table 4 - Final logistic regression model of overweight predictors in young adult student children and boys, Fortaleza, Ceará, Brazil, 2016

\begin{tabular}{|c|c|c|c|c|c|}
\hline \multirow{2}{*}{ Variables } & \multirow{2}{*}{ B (SE) } & \multirow{2}{*}{$p$ value } & \multicolumn{3}{|c|}{ Confidence Interval of $95 \%$ for Exp b } \\
\hline & & & Inferior & Exp b & Superior \\
\hline Constant & $-1.732(0.430)$ & 0.000 & & 0.177 & \\
\hline $\begin{array}{l}\text { Weight in child- } \\
\text { hood }\end{array}$ & $1.588(0.392)$ & 0.000 & 2.271 & 4.893 & 10.544 \\
\hline Age of menarche & $0.877(0.256)$ & 0.001 & 1.454 & 2.403 & 3.972 \\
\hline
\end{tabular}

Note: $B(S E)=$ Standard Error; $P$ value: significance level; $R 2=0.10$ (Cox \& Snell), 0.11 (Nagelkerke). $X^{2}$ of the model $=29.83, p=0.000$.

\section{DISCUSSION}

Overweight, translated as an increase in the body mass index, is reaching increasingly younger populations and, according to the literature, has been of relevance among the female population, which is a source of concern, supporting the discussions in this study ${ }^{(14-16)}$.

Young women, because they are more vulnerable to the pressures of socio-cultural, economic and aesthetic patterns, end up being the group at greatest risk for the development of eating disorders, which have multiple causes, including genetic, environmental and behavioral factors ${ }^{(17)}$. The young female adult school population is a group not yet widely discussed in the literature regarding the nutritional situation, although it is perceived that there are promising fields and contributions related to this theme.

There are associations between socio-demographic characteristics and the risk of overweight, with different behaviors between men and women, and in the different regions, considering lifestyle and developmental factors that may be discrepant according to the study site ${ }^{(14,16-18)}$. Current literature indicates that young adults are at risk of gaining excess weight in the transition from childhood or adolescence to the adulthood of their lives. The most critical periods for the development of overweight are in early childhood, during the strong oscillation in the trajectory of body adiposity, which occurs between five and seven years and in adolescence ${ }^{(19)}$.

When investigating the history of weight gain, young adult women with overweight in childhood and adolescence were more likely to have overweight in adulthood, according to the bivariate analysis, but only overweight in childhood remained significant in the final multivariate analysis.

The literature highlights the age of about six years as the most critical periods in the development of more body fat accumulation ${ }^{(8)}$, being the occurrence of obesity, according to the distribution by sex and age, evidenced with high risk in 
girls ${ }^{(20)}$. From approximately six years, one in two obese children becomes an obese adult, while only one in ten non-obese children reaches the same adult outcome ${ }^{(19)}$. These data show that the problem of overweight is present, from childhood, giving continuity in adolescence, and may lead to persistence of overweight in the adult life of these women, bringing a baggage of losses to health, in the short and long term.

Factors related to women's reproductive function received a special focus in this study. Age of menarche was an important determinant of overweight, standing out significantly among several other variables analyzed. In the present study, women who presented menarche under the age of 12 years were three times more likely to have overweight according to the bivariate analysis, remaining significant in the final regression model. Menarche at an early age, ie before 12 years, increases the risk of overweight by $59 \%{ }^{(14-15)}$. Early maturing girls presented higher weight and higher risk of overweight ${ }^{(21)}$.

Numerous factors have been related to sexual maturation, exerting influence on the age of menarche. Among these factors, we highlight the social class and history of obesity. Girls of higher and obese social classes menstruate earlier ${ }^{(22)}$. However, the fact that girls menstruate earlier has been associated with more evidence to the increase in the prevalence of overweight and obesity, and less related to social conditions ${ }^{(16,23)}$. This association is worrying, as puberty has tended to occur earlier and earlier, with an estimated age of menarche decreasing by three to four months each decade. From this fact, it is presumed that the increasingly precocious menarche may lead to new cases of overweight, impacting on the prevalence of this disease and its complications ${ }^{(15,22)}$.

Reducing the prevalence of overweight in women from childhood, in fact, implies important gains in terms of physical and mental health, such as controlling severe chronic diseases and increasing the sense of self-esteem of these women, and to this end investing (reduction of overweight) and secondary (reduction of obesity) $)^{(15)}$.

\section{Study limitations}

Despite the evaluation of the occurrence of overweight in young adult school children and the identification of the factors involved, it is important to point out the memory bias that may have occurred in relation to the identification of weight in childhood and adolescence, as well as age of menarche.

\section{Contributions to the sectors of Nursing, Health or Public Policy}

The results of this research allowed the analysis and identification of the factors involved in the context of overweight in young adult school girls, besides allowing the recognition of individuals or groups more vulnerable, as well as subsidizing the planning of measures and strategies of prevention and control of this aggravation, guaranteeing the quality of care. In the school setting, the nurse, when promoting health education, aims to conduct behaviors and attitudes in order to motivate the young adult women's awareness that their health is closely related to their lifestyle, as well as to promote educational strategies that minimize risks to which young women are exposed to overweight, urging them to live a healthy life. These actions should start from infancy and continue throughout the life cycle of the woman.

\section{CONCLUSION}

Overweight in childhood and early menarche increase the chances of women having overweight in young adulthood, ie characteristics related to nutritional status in earlier stages of life and gynecological issues are associated with the aggravation in question. In a complementary way, it can be deduced that excess weight in childhood may have led to acceleration in the maturation of women, leading to premature menarche and, consequently, overweight in adult life. Despite the importance of these results, it is necessary to investigate in later studies that other factors may influence overweight, considering that the predictor variables partially explain the outcome.

\section{FUNDING}

This study integrates an "umbrella" project funded by the National Council for Scientific and Technological Development (Conselho Nacional de Desenvolvimento Científico e Tecnológico).

\section{REFERENCES}

1. Parto P, Lavie CJ. Obesity and cardiovascular diseases. Minerva Med[Internet]. 2017[cited 2017 Nov 01];42(11):376-94. Available from: https://www.ncbi.nlm.nih.gov/pubmed/28150485

2. Florêncio RS, Santiago JCS, Moreira TMM, Freitas TC. Excessive weight and sociodemographic vulnerability markers in young adult students. Acta Paul Enferm[Internet]. 2016[cited 2017 Nov 01];29(4):413-20. Available from: http://www.scielo.br/pdf/ape/ v29n4/en_1982-0194-ape-29-04-0413.pdf

3. Mariz LS, Medeiros CCM, Vieira CENK, Enders BC, Coura AS. Changes in the frequency of food intake among. Rev Latino-Am Enfermagem[Internet]. 2013[cited 2017 Nov 01];21(4):973-81. Available from: https://www.ncbi.nlm.nih.gov/pubmed/23970236

4. Souza MCC, Tibúrcio JD, Bicalho MF, Rennó MS, Dutra JS, Campos LG, et al. Factors associated with obesity and overweight in school-aged children. Texto Contexto Enferm[Internet]. 2014[cited 2017 Nov 03];23(3):712-9. Available from: http://www.scielo. br/pdf/tce/v23n3/pt 0104-0707-tce-23-03-00712.pdf

5. Tralhão A, Sousa PJ, Ferreira AM, Miranda M, Monge JC, Tomé A, et al. Cardiovascular risk profile of young adults: chances over time. Rev Port Cardiol[Internet]. 2014[cited 2017 Nov 01];33(3):147-54. Available from: https://www.sciencedirect.com/science/ 
article/pii/S2174204914000555

6. Dietz WH. Obesity and excessive weight gain in young adults: new targets for prevention. JAMA[Internet]. 2017 [cited 2017 Nov 02];318(3):241-2. Available from: https://www.ncbi.nlm.nih.gov/pubmed/28719674

7. Gomes EB, Moreira TMM. Cardiovascular risk stratification in young adults: relation to blood pressure, and found anthropometry biochemical. Rev Pesqui: Cuid Fundam[Internet]. 2014[cited 2017 Nov 01];6(3):918-28. Available from: http://www.seer.unirio. br/index.php/cuidadofundamental/article/view/3139/pdf_1332

8. Santiago JCS, Moreira TMM, Florêncio RS. Association between overweight and characteristics of young adult students: support for nursing care. Rev Latino-Am Enfermagem[Internet]. 2015[cited 2017 Nov 01];23(2):250-8. Available from: http://www.scielo. br/pdf/rlae/v23n2/0104-1169-rlae-23-02-00250.pdf

9. Florêncio RS, Moreira TMM, Silva MRF, Almeida ILS. Overweight in young adult students: the vulnerability of a distorted selfperception of body image. Rev Bras Enferm[Internet]. 2016[cited 2017 Nov 01];69(2):258-65. Available from: http://www.scielo. br/pdf/reben/v69n2/en_0034-7167-reben-69-02-0258.pdf

10. Associação Brasileira para o Estudo da Obesidade e da Síndrome Metabólica-ABESO. Diretrizes Brasileiras de Obesidade 2016[Internet]. 4.ed. São Paulo, SP: ABESO; 2016[cited 2018 Mar 23]. Available from: http://www.abeso.org.br/uploads/ downloads/92/57fccc403e5da.pdf

11. Pellegrini PG, Silva IM, Barreto M, Crepaldi MA. Diferenciação do adulto jovem: um estudo de caso em atendimento familiar. Pensando Fam[Internet]. 2015[cited 2017 Nov 01];19(1):114-29. Available from: http://pepsic.bvsalud.org/pdf/penf/v19n1/ v19n1a10.pdf

12. Silva KL, Sena RR, Gandra EC, Matos JAV, Coura KRA. Health promotion in the school health programme and nursing inclusion. Rev Min Enferm[Internet]. 2014[cited 2017 Nov 01];18(3):623-9. Available from: http://www.reme.org.br/artigo/detalhes/950

13. Brasil. Ministério da Saúde. Conselho Nacional de Saúde. Resolução n. 466/12. Dispõe sobre diretrizes e normas regulamentadoras de pesquisas envolvendo seres humanos[Internet]. Brasília: Conselho Nacional de Saúde; 2012[cited 2017 Nov 01]. Available from: http://bvsms.saude.gov.br/bvs/saudelegis/cns/2013/res0466_12_12_2012.html

14. Lins APM, Sichieri R, Coutinho WF, Ramos EG, Peixoto MVM, Fonseca VM. Healthy eating, schooling and being overweight among low-income women. Ciênc Saúde Colet[Internet]. 2013[cited 2017 Nov 01];18(2):357-66. Available from: http://www. scielo.br/pdf/csc/v18n2/07.pdf

15. Machado IE, Pereira SCL, Dias Jr CS, Abreu MNS, Borges AM, Filgueiras JH. Factors associated with being overweight among adults using low-budget restaurants in Belo Horizonte, Brazil. Ciênc Saúde Colet[Internet]. 2014[cited 2017 Nov 01];19(5):136777. Available from: http://www.scielo.br/pdf/csc/v19n5/1413-8123-csc-19-05-01367.pdf

16. Ferreira RAB, Benicio MHA. Obesity in Brazilian women: association with parity and socieconomic status. Rev Panam Salud Publica[Internet]. 2015[cited 2017 Nov 03];37(4/5):337-42. Available from: https://www.scielosp.org/pdf/rpsp/2015.v37n4-5/337-342/pt

17. Pavey TG, Peeters GMEEG, Gomersall SR, Brown WJ. Long-term effects of physical activity level on changes in healthy body mass index over 12 years in young adult women. Mayo Clin Proc[Internet]. 2016[cited 2017 Nov 01];91(6):735-44. Available from: http://www.mayoclinicproceedings.org/article/S0025-6196(16)30036-2/fulltext

18. Sabóia RS, Araújo AP, Barbosa JMA, Galvão CEP, Cruvell JMS, Ferreira SCN. Abdominal obesity and associated factors among adults attending a university health center. Rev Bras Promoç Saúde[Internet] 2016[cited 2017 Nov 01];29(2):259-67. Available from: http://periodicos.unifor.br/RBPS/article/view/4130

19. Reed ZE, Micali N, Bulik CM, Smith GD, Wade KH. Assessing the casual role of adiposity on disordered eating in chilhood, adolescence, and adulhood: a Mendelian randomization analysis. Am J Clin Nutr[Internet]. 2017[cited 2017 Nov 02];106(3):76472. Available from: https://www.ncbi.nlm.nih.gov/pmc/articles/PMC5573023/pdf/ajcn154104.pdf

20. Freitas AE, Lamounier JA, Soares DD, Oliveira TH, Lacerda DR, Andrade JB, et al. Adiposity and metabolic profile of schoolchildren in the urban areas of Ouro Preto, Minas Gerais. Rev Med Minas Gerais[Internet]. 2013[cited 2017 Nov 01];23(1):5-12. Available from: http://rmmg.org/artigo/detalhes/3

21. Oliveira JR, Frutuoso MFP, Gambardella AMD. Association among sexual maturation, overweight and central adiposity in children and adolescents at two schools in São Paulo. J Human Growth Develop[Internet]. 2014[cited 2017 Nov 01];24(2):201-7. Available from: http://pepsic.bvsalud.org/pdf/rbcdh/v24n2/pt_13.pdf

22. Castilho SD, Nucci LB. Age at menarche in schoolgirls with and without excess weight. J Pediatr[Internet]. 2015 [cited 2017 Nov 01];91(1):75-80. Available from: http://www.scielo.br/pdf/jped/v91n1/0021-7557-jped-91-01-00075.pdf

23. Villamor E, Jansen EC. Nutritional determinants of the timing of puberty. Annu Rev Public Health[Internet]. $2016[\mathrm{cited} 2017$ Nov 01];37:33-46. Available from: https://www.ncbi.nlm.nih.gov/pubmed/26789387 